\title{
SCENARIO OF ACUTE LYMPHOBLASTIC LEUKAEMIA IN GWALIOR REGION
}

\author{
K. S. Mangal ${ }^{1}$, K. K. Magnani2 ${ }^{2}$ Jyoti Priyadarshini Shrivastava ${ }^{3}$, Lokesh Tripathi', Rajesh Gaur ${ }^{5}$ \\ ${ }^{1}$ Associate Professor, Department of Pathology, Gajra Raja Medical College, Gwalior. \\ ${ }^{2}$ Associate Professor, Department of Pathology, Gajra Raja Medical College, Gwalior. \\ ${ }^{3}$ Associate Professor Department of Pathology, Gajra Raja Medical College, Gwalior. \\ 4 Post Graduate, Department of Pathology, Gajra Raja Medical College, Gwalior. \\ 5 Professor, Department of Pathology, Gajra Raja Medical College, Gwalior.
}

\section{ABSTRACT}

\section{BACKGROUND}

Leukaemia is the most prevalent childhood cancer and Acute Lymphoblastic Leukaemia (ALL) constitutes about $75 \%$ of all cases. The most frequent presenting symptoms are fever, weight loss and pallor. Early diagnosis of this haematological malignancy can be helpful for prognosis of disease.

\section{AIMS AND OBJECTIVES}

The objectives of the present study were to assess frequency of presenting symptoms, laboratory data and prognostic factors in children with diagnosis of ALL.

\section{MATERIALS AND METHODS}

The present study (2014) was performed in the Department of Pathology of Gajra Raja Medical College, Gwalior, over a period of one year from October 2013 to September 2014. The blood samples were received from patients attending various Departments of Jayarogya Groups of Hospitals, a tertiary care hospital.

\section{RESULTS}

Out of the 37 cases diagnosed as Acute Lymphoblastic Leukaemia, 25 (67.57\%) were male and 12 (32.43\%) were female, (male:female ratio: 2.1:1); 43.35\% of patients which comprises highest number of cases belonged to 11-20 years of age group. The most frequent presenting symptoms was fever (83.78\%) followed by weakness $(70.27 \%)$ and loss of appetite (27\%), while most frequent presenting sign was pallor (86.48\%) followed by lymphadenopathy $(67.57 \%)$ and splenomegaly (48.65\%)). Complete blood cell count was abnormal in all of the patients and pancytopenia was detected in $10.81 \%$ of the patients. Of all the patients, 91.89\% had abnormal White Blood Cell (WBC) count at presentation with about 80\% were presented with Leukocytosis. FAB L1 subtype was more common as compared to FAB L2 subtype.

\section{CONCLUSION}

In our study (2014), Acute Lymphoblastic Leukaemia was more prevalent in males than in females and more common in childhood than in adult. FAB L1 subtype was more common as compared to FAB L2 subtype.

\section{KEYWORDS}

Leukaemia, Acute Lymphoblastic Leukaemia, Symptoms, Haematology.

HOW TO CITE THIS ARTICLE: Mangal KS, Magnani KK, Shrivastava JP, et al. Scenario of acute lymphoblastic leukaemia in Gwalior region. J. Evolution Med. Dent. Sci. 2016;5(31):1656-1658, DOI: 10.14260/jemds/2016/390

\section{INTRODUCTION}

Leukaemias are neoplastic proliferations of haematopoietic cells and form a major proportion of haematopoietic neoplasms that are diagnosed worldwide. Acute lymphoblastic leukaemias are haematologic malignancies with increased numbers of lymphoid blasts. The term acute historically referring to a rapid onset and promptly fatal outcome, now indicates the relatively undifferentiated nature of the leukaemic cells. Acute Lymphoblastic Leukaemia (ALL) is the most common leukaemia in children accounting for approximately $80 \%$ of paediatric cases.[1]

Financial or Other, Competing Interest: None.

Submission 28-01-2016, Peer Review 24-03-2016,

Acceptance 31-03-2016, Published 14-04-2016.

Corresponding Author:

Jyoti Priyadarshini Shrivastava

\#155, Saraswati Nagar, University Road,

Gwalior-474011,

Madhya Pradesh.

E-mail: drpriyajyoti22@gmail.com

DOI: $10.14260 /$ jemds $/ 2016 / 390$
Diagnosing the type and sub-type of leukaemia is very important as the therapy, prognosis and survival rate changes with each type and sub-types. Present study is planned to assess the "Acute lymphoblastic leukaemia" cases and its subtypes to diagnose by morphological features and to clinically correlate the various clinical and laboratory parameters with relation to subtypes of "ALL" in the patients attending the J. A. Group of Hospitals (A tertiary care hospital), Gwalior, MP.

\section{AIMS AND OBJECTIVES}

Aims of the present study to find out total prevalence of Acute Lymphoblastic Leukaemia including their morphological subgroups classified according to FAB classification.

\section{MATERIAL AND METHODS}

Present study were performed, planned over a period of 12 months from October 2013 to September 2014. Peripheral venous blood and bone marrow aspirate samples of suspected leukaemic patients received at the Department of 
Pathology, G. R. Medical College and J. A. Group of Hospitals, Gwalior, were studied.

Bone marrow aspirate and peripheral blood smear samples from patients of all age groups who presented with clinical features and abnormal haematological findings suggestive of acute leukaemia were included in the study. Patients who dropped out of the study before complete workup, due to death or discharge against medical advice or lost during followup were excluded. The relevant clinical history was obtained in each case, routine blood counts performed and peripheral smear studied in detail. Bone marrow aspiration were done in each case and the morphology of the smears of aspirate were studied in detail.

Cases were sorted age and gender wise, key haematological parameter wise as well as they were classified on the basis of FAB classification according to their morphological characteristics.

\section{RESULT}

During the study period from October 2013 to September 2014, total 81 blood and bone marrow aspirate samples from leukaemic cases were studied in the Department of Pathology, Gajra Raja Medical College, Gwalior, Madhya Pradesh.

Total 81 cases of acute leukaemia were studied, out of total $81(100 \%)$ cases of acute leukaemia, 37 (45.68\%) cases were ALL and 44 (54.32\%) cases were AML as depicted in Table 1.

\begin{tabular}{|c|c|c|c|c|}
\hline \multirow{2}{*}{$\begin{array}{c}\text { Total Cases of Acute } \\
\text { Leukaemia }\end{array}$} & \multicolumn{2}{|c|}{ ALL } & \multicolumn{2}{c|}{ AML } \\
\cline { 2 - 5 } & No. & $\%$ & No. & $\%$ \\
\hline 81 & 37 & 45.68 & 44 & 54.32 \\
\hline Table 1: Major Subtypes of Acute Leukaemia \\
\hline
\end{tabular}

Out of total $37(100 \%)$ cases of ALL, there were 25 $(67.57 \%)$ male patients and $12(32.43 \%)$ female patients as shown in Table 2.

\begin{tabular}{|c|c|c|c|}
\hline \multirow{2}{*}{$\begin{array}{l}\text { Sl. } \\
\text { No. }\end{array}$} & \multirow{2}{*}{ SEX } & \multicolumn{2}{|c|}{ ALL } \\
\hline & & No. & $\%$ \\
\hline 1. & MALE & 25 & 67.57 \\
\hline 2. & FEMALE & 12 & 32.43 \\
\hline \multicolumn{2}{|c|}{ TOTAL } & 37 & 100 \\
\hline & Distrik & Tota & ses \\
\hline
\end{tabular}

Highest number of ALL cases 16 (43.35\%) were seen in 11 to 20 years of age group followed by 0 to 10 years' age group, where total 14 cases (37.84\%) were seen. Least number of cases $1(2.7 \%)$ were found in 31 to 40 years and 1 case $(2.7 \%)$ also in 41 to 50 years' age group. None of the cases were found above 51 years of age group as depicted in Table 3.

\begin{tabular}{|c|c|c|c|}
\hline Sl. No. & Age in Years & \multicolumn{2}{|c|}{ ALL } \\
\hline 1 & $0-10$ & 14 & 37.84 \\
\hline 2 & $11-20$ & 16 & 43.35 \\
\hline 3 & $21-30$ & 05 & 13.5 \\
\hline 4 & $31-40$ & 01 & 2.7 \\
\hline 5 & $41-50$ & 01 & 2.7 \\
\hline 6 & $51-60$ & 0 & 0 \\
\hline \multicolumn{4}{|c|}{ TOTAL } \\
\hline
\end{tabular}

In the present study, majority of ALL patients 31 cases $(83.78 \%)$ had fever followed by weakness 26 cases $(70.27 \%)$, lymphadenopathy 25 cases (67.57\%) and splenomegaly 18 cases $(48.65 \%)$, loss of appetite 10 cases $(27 \%)$ and sternal tenderness 8 cases $(21.62 \%)$ as shown in Table 4.

\begin{tabular}{|c|c|c|c|}
\hline \multirow{2}{*}{$\begin{array}{c}\text { Sl. } \\
\text { No. }\end{array}$} & \multirow{2}{*}{ Symptoms/Sign } & \multicolumn{2}{|c|}{ ALL } \\
\cline { 3 - 4 } & & No. & \% \\
\hline 1 & Fever & 31 & 83.78 \\
\hline 2 & Weakness & 26 & 70.27 \\
\hline 3 & Lymphadenopathy & 25 & 67.57 \\
\hline 4 & Splenomegaly & 18 & 48.65 \\
\hline 5 & Loss of appetite & 10 & 27 \\
\hline 6 & Sternal tenderness & 8 & 21.62 \\
\hline 7 & Loss of weight & 6 & 16.21 \\
\hline 8 & Cough & 2 & 5.4 \\
\hline 9 & Epistaxis & 2 & 5.4 \\
\hline 10 & Squint & 1 & 2.7 \\
\hline \multicolumn{4}{|c}{ Table 4: Clinical Presentation } \\
\hline
\end{tabular}

Total leukocyte count at the first presentation showed that majority of cases 14 (37.84\%) showed TLC within 11,000 to $49,900 / \mathrm{cmm}$ group, followed by 8 cases $(21.62 \%)$ in 50,000 to $99,900 / \mathrm{cmm}$ TLC group. Least number of cases, 2 (5.4\%) showed TLC more than $2.0 \mathrm{lac} / \mathrm{cmm}$ as depicted in Table 5 .

\begin{tabular}{|c|c|c|c|}
\hline \multirow{2}{*}{$\begin{array}{c}\text { Sl. } \\
\text { No. }\end{array}$} & \multirow{2}{*}{$\begin{array}{c}\text { Total WBC } \\
\text { Count/cumm }\end{array}$} & $\begin{array}{c}\text { No. of } \\
\text { Cases }\end{array}$ & $\begin{array}{c}\text { \% of } \\
\text { Cases }\end{array}$ \\
\cline { 3 - 4 } & Less than 4000 & 4 & 10.81 \\
\hline 1 & $4,000-11,000$ & 3 & 8.11 \\
\hline 2 & $11,100-49,900$ & 14 & 37.84 \\
\hline 3 & $50,000-99,900$ & 8 & 21.62 \\
\hline 4 & 1.0 lac -2.0 lac & 6 & 16.22 \\
\hline 5 & More than 2.0 lac & 2 & 5.4 \\
\hline 6 & TOTAL & 37 & $\mathbf{1 0 0}$ \\
\hline \multicolumn{3}{|c|}{ Table 5: Leukocyte Count on First Presentation } \\
\hline \multicolumn{3}{|c|}{}
\end{tabular}

The blast counts on the first presentation of ALL patients showed that majority of ALL cases, 21 cases (56.76\%) showed blast cells between 50 to $80 \%$ followed by 8 cases $(21.63 \%)$ showed more than $80 \%$ blast cells. Least number of 1 case $(2.7 \%)$ was found to have less than $20 \%$ of blast cells as shown in Table 6.

\begin{tabular}{|c|c|c|c|}
\hline \multirow{2}{*}{$\begin{array}{l}\text { Sl. } \\
\text { No. }\end{array}$} & \multirow{2}{*}{$\begin{array}{c}\text { No. of } \\
\text { Blasts (\%) }\end{array}$} & \multicolumn{2}{|c|}{ ALL } \\
\hline & & No. & $\%$ \\
\hline 1 & Less than $20 \%$ & 1 & 2.7 \\
\hline 2 & $20 \%-49 \%$ & 7 & 18.91 \\
\hline 3 & $50 \%-80 \%$ & 21 & 56.76 \\
\hline 4 & More than $80 \%$ & 8 & 21.63 \\
\hline & TOTAL & 37 & 100 \\
\hline
\end{tabular}

In present study, majority of cases 21 (56.75\%) were recorded in FAB subtype L1 group in which male preponderance 16 cases $(76.2 \%)$ was seen in male. Likewise, in L2 FAB subtype group majority 16 cases (43.25\%) also 
showed male preponderance, as 9 cases (56.25\%) were male In FAB subtype L3, none of the cases were found as depicted in Table 7.

\begin{tabular}{|c|c|c|c|c|c|c|c|}
\hline \multirow{2}{*}{$\begin{array}{c}\text { Sl. } \\
\text { No. }\end{array}$} & \multirow{2}{*}{$\begin{array}{c}\text { Sub- } \\
\text { Type }\end{array}$} & \multicolumn{2}{|c|}{ ALL } & \multicolumn{2}{c|}{ Male } & \multicolumn{2}{c|}{ Female } \\
\hline 1 & L1 & 21 & 56.75 & 16 & 76.2 & 05 & 23.8 \\
\hline 2 & L2 & 16 & 43.25 & 09 & 56.25 & 07 & 43.75 \\
\hline 3 & L3 & 0 & 0 & 0 & 0 & 0 & 0 \\
\hline \multicolumn{2}{|c|}{ TOTAL } & $\mathbf{3 7}$ & $\mathbf{1 0 0}$ & $\mathbf{2 5}$ & $\mathbf{6 7 . 5 7}$ & $\mathbf{1 2}$ & $\mathbf{3 2 . 4 3}$ \\
\hline
\end{tabular}

Table 7: FAB Subtype of Acute Lymphoblastic Leukaemias

\section{DISCUSSION}

In the present study (2014), male-to-female ratio was 2:1 in Gwalior region of India. Regarding the male-to-female ratio in ALL patients, there is overall consensus in various studies like Zauhir et al. 2005 (2.3:1).[2]; Abdelrazzaq Wriekat et al. 2008 (1.7:1).[3] and Fatima B. et al. 2007 (1.5:1).[4] that ALL cases are more prevalent in males as compared to females.

As far as age group of the ALL patients are concerned, the findings of present series (2014) are largely similar to that of Laishram RS et al. (2011).[5] study with minor deviation and possibly this difference of minor differing trends of age group is due to different geographic regions of study area.

In present study (2014), only (40.5\%) of ALL cases showed TLC less than $25,000 / \mathrm{cmm} ; 16.3 \%$ were presented with TLC of $25000-50000 /$ cumm, while $21.7 \%$ cases were with more than $1 \mathrm{lac} / \mathrm{cumm}$ count. There are wide variation in TLC count of the patient presented with ALL in various other similar studies like.

Almasi HA et al. (2008).[6] and Somsuvra B. Ghatak et al. (2008).[7] This can be explainable by the fact that ALL cases have many reasons and ways by which bone marrow suppression occurs and therefore due to variation of causes, there are variable results.

The present study (2014) also showed high prevalence of L1 FAB subtype (56.75\%) and the findings of present study are in consensus with results of Mirza Naqi Zafar, 1985 (55\%).[8] Miller et al. 1981 (85\%).[9] Hann et al. 1979 (73\%).[10] Viana et al. 1980 (71\%).[11] Bennet et al. 1986 (63\%).[12] and Khalid Hassan et al. 1993 (61.2\%).[13]

\section{CONCLUSION}

The present study concluded that the Acute Lymphoblastic Leukaemia was more prevalent in males than in females and more common in childhood than in adult. FAB L1 subtype was more common as compared to FAB L2 subtype.

\section{REFERENCES}

1. Ross JA, Davies SM, Potter JD, et al. Epidemiology of childhood leukemia, with a focus on infants. Epidemiol Rev 1994;16(2):243-72.

2. Zuhair A Ali Al-Barazanchi, AK Al-Sani, Nadheera Fnaema. Haematological and cytomorphological study of acute lymphoblastic leukemia (ALL). Bahrain Medical Bulletin 2005;27(4):1-4.

3. Abdelrazzaq Wriekat, Maher Khader, Nazih AbuAlsheikh, et al. Acute leukemia at king hussein medical center: a retrospective review. JRMS 2008;17(4):11-4.

4. Fatima Bachir, Sanae Bennani, Ali Lahjouji, et al. Characterization of acute lymphoblastic leukemia subtypes in moroccan children. International Journal of Pediatrics Article ID 674801, 2009;2009:1-7.

5. Laishram RS, Singh NB, Laishram S, et al. Pattern of leukaemias in a tertiary care hospital - a 5 years retrospective study of 103 cases. Indian Medical Gazette 2013;147(5):175-80.

6. Amir Almasi-Hashiani, Soheil Zareifar, Mehran Karimi, et al. Survival rate of childhood leukemia in shiraz, Southern Iran. Iran J Pediatr 2013;23(1):53-8.

7. Somsuvra B Ghatak, Ashwin P Patel, Jagruti A Patel. Profile of 52 cases of leukemia-a retrospective analysis with special reference to immunophenotyping. Journal of Pharmacy Research 2010;3(8):1875-9.

8. Zafar MN. FAB classification of acute lymphoblsstic leukaemia (ALL) and its relevance to ALL in Karachi children. JPMA 1985;35:233-6.

9. Miller DR, Leikin S, Albo V, et al. Prognostic importance of morphology (FAB classification) in childhood acute lymphoblastic leukemia (ALL). $\mathrm{Br} \quad \mathrm{J}$ Haemtol 1981;48(2):199-206.

10. Hann IM, Evans DIK, Palmer MK, et al. The prognostic significance of morphological features in childhood acute lymphoblastic leukaemia. J Clin Lab Haematol 1979;1(3):215-26.

11. Viana MB, Maurer HS, Ferenc C. Subclassification of acute lymphoblastic leukaemia in children: analysis of the reproducibility of morphological criteria and prognostic implications. Br J Haematol 1980;44(3):3838.

12. Bennett JM, Catovsky D, Daniel MT, et al. Proposals for the classification of the acute leukaemias frenchAmerican-british (FAB) co-operative group. $\mathrm{Br}$ J Haematol 1976;33(4):451-8.

13. Khalid Hassan, Nadeem Ikram, Sajid Hussain Shah. A morphological pattern of 234 cases of leukemias. Patients and Methods Patients 1985-1993;145-8. 